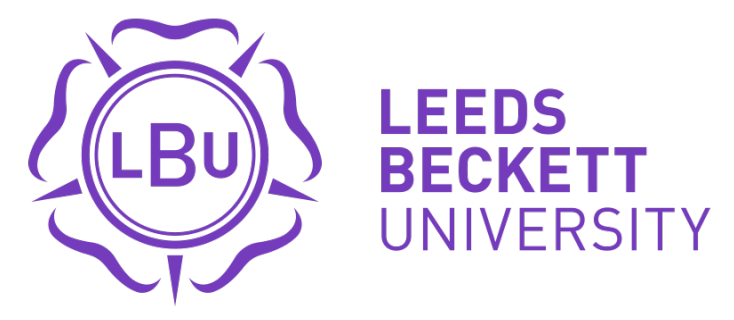

Citation:

Sterchele, D and Saint-Blancat, C (2015) Keeping it liminal. The Mondiali Antirazzisti (Anti-racist World Cup) as a multifocal interaction ritual. Leisure Studies, 34 (2). 182 - 196. ISSN 0261-4367 DOI: https://doi.org/10.1080/02614367.2013.855937

Link to Leeds Beckett Repository record:

https://eprints.leedsbeckett.ac.uk/id/eprint/1781/

Document Version:

Article (Accepted Version)

The aim of the Leeds Beckett Repository is to provide open access to our research, as required by funder policies and permitted by publishers and copyright law.

The Leeds Beckett repository holds a wide range of publications, each of which has been checked for copyright and the relevant embargo period has been applied by the Research Services team.

We operate on a standard take-down policy. If you are the author or publisher of an output and you would like it removed from the repository, please contact us and we will investigate on a case-by-case basis.

Each thesis in the repository has been cleared where necessary by the author for third party copyright. If you would like a thesis to be removed from the repository or believe there is an issue with copyright, please contact us on openaccess@leedsbeckett.ac.uk and we will investigate on a case-by-case basis. 
To cite this article: Sterchele, D., \& Saint-Blancat, C. (2015). Keeping it liminal. The Mondiali Antirazzisti (Anti-racist World Cup) as a multifocal interaction ritual, Leisure Studies, 34:2, 182-196, DOI: 10.1080/02614367.2013.855937

To link to this article: http://dx.doi.org/10.1080/02614367.2013.855937

$* * *$

\section{Keeping it liminal. The Mondiali Antirazzisti (Antiracist World Cup) as a multifocal interaction ritual}

This paper examines how social mixing and celebration of diversity can be enabled through sports festivals marked by their carnivalesque atmosphere. Our analysis draws on a longitudinal ethnographic study of the Mondiali Antirazzisti (Antiracist World Cup), a non-competitive football tournament and intercultural festival featuring the yearly participation of hardcore football fans (ultras), migrant groups, third-sector associations and other informal groups. We consider how the multifocal ritual form of the event helps to create a liminal space in which discrimination and stereotypes can be temporarily challenged. The sources of collective effervescence are multiplied by placing sport games within a wider range of other leisure and cultural activities, thus promoting internal diversity and the inclusion of outsiders. Additionally, social boundaries are also blurred by not emphasising the competitive dimension of the sporting activities, making sporting categorizations more fluid, and breaking down the separation between protagonists and spectators. Nonetheless, considering the transient character of liminality, we also investigate problems and limitations implied by the pursuit of these objectives. It is concluded that, despite a certain degree of selfreferentiality, the festival fosters the spreading of anti-discriminatory cultures by enhancing the participants' reflexivity and feeding their commitment in generating spin-off activities in different local contexts.

Key words: liminality - multifocal ritual - sport festival - antiracism

6 July, 2012. Friday afternoon draws to an end, as we walk among the thousands of people crowding the huge park of the Mondiali Antirazzisti (Antiracist World Cup, henceforth MA) in the northern Italian countryside. We hear laughter and loud merry voices echoing from the fields: 36 teams are playing football simultaneously, while DJs play music and other participants eat and drink together in the restaurant-tents. In 
another area, some attend a book presentation, while others participate in traditionaldancing classes. Many have already returned to the camping area to rest, shower, and prepare for the evening: soon market stands, concerts and outdoor video-projections will take the place of football matches. An atmosphere of carnival and laughter characterises this multicultural festival in which music, colours and fun are more important than sporting victories and results. Football and other recreational sports are mixed with a broad range of musical, cultural and social activities, with the aim of fostering the encounter between different, often marginalised/stigmatised, and sometimes conflicting social actors.

Created in 1997 as a workshop on the themes of violence and discrimination among football supporters (notably the hardcore supporters commonly known as ultras), the MA have steadily grown from the original eight teams, to now encompass more than 200 teams and 7,000 participants from approximately 25 different countries. The typology of the participants has also evolved, becoming more complex and diverse: no longer only Italian and foreign ultras, but also teams composed of migrant groups, members of anti-racism and human rights associations, informal groups of people interested in anti-racism or simply attracted by the lively atmosphere. The MA is organised by the Progetto Ultrà Association, supported by UISP (Unione Italiana Sport Per tutti), an important 'sport for all' body characterised by left-wing political orientation and active within the Italian and international antiracist movement (Ruzza, 2008). The festival can be considered as a benchmark in the wider spectrum of initiatives carried out within the network FARE (Football Against Racism in Europe).

Like other events (Burdsey, 2008), the MA turns a sport tournament into a fullblown festival (Falassi, 1987), utilising leisure as a context to promote social change (Hemingway, 1999). The conditions and modalities through which the festive dimension of these civil leisure events (Mair, 2002/03) increases or limits their socio- 
political impact (Sharpe, 2008) need to be questioned. Several studies have explored the contribution of sports events in shaping social identities and intercultural relations, overcoming social boundaries, downplaying interpersonal and intergroup discriminations. Such events have been analysed for their potential to influence national and ethnic belonging (Dallaire \& Denis, 2005), integrate marginalised groups (Krowel, Boonstra, Duyvendak, \& Veldboer, 2006; Sherry, 2010), promote gender equality (Elling, De Knop, \& Knoppers, 2003), and reconcile divided communities (Gasser \& Levinsen, 2004; Schulenkorf, 2010; Sorek, 2003; Sterchele, 2007; Sugden, 2006). Nonetheless, while scholars are usually asked to evaluate the extent of the events' impact (Coalter, 2007; Long \& Sanderson, 2001), there is still a relative scarcity of theoretically underpinned research into the processes by which these impacts can be generated (Chalip, 2006). Indeed, alongside trying to evaluate to what extent sport festivals actually do promote inclusive social change, we also need to study how they (seek to) achieve this goal. According to Handelman (1990, pp. 16-17), 'if public events are constructs that make order, then the logics of how they are put together is crucial to how they work' and to what 'their designs enable them to accomplish.' As the events' organization - their 'logic of composition', in Handelman's words - is integral to their enactment, we need to explore how the shape and design of sport festivals affect their performance.

We address this issue by analysing how the MA try to engender and maintain a liminal space which temporarily de-structures and/or subverts the usual social categorisations, hierarchies, and representations (Turner, 1982). We pay particular attention to the role played by sport within the event and the ways it is managed for such a purpose. After outlining the theoretical and methodological background underpinning our research, we develop our analysis into three parts. Firstly, we examine how the multifocal shape of the MA enables internal liminality and social mixing, thus 
blurring inner boundaries and favouring interaction between diverse participant groups. Secondly, we analyse how external boundaries are kept porous by promoting openness towards potential new participants, the community hosting the event, and external visitors. Lastly, we investigate problems and limitations implied by the pursuit of these objectives.

\section{Liminality, anti-structure and multifocal rituals}

According to Victor Turner (1979, p. 465), liminality is 'a state or process which is betwixt-and-between the normal, day-to-day cultural and social states and processes.' It can be considered the realm of possibility (of 'subjunctive worlds', in Turner's terms), a space for exploration and social change. Despite their different backgrounds and belongings, people experiencing liminality together can feel as though they are part of a communitas, that is 'a community or comity of comrades and not a structure of hierarchically arrayed positions' (Turner 1967, p. 100). With the term anti-structure Turner described both liminality and communitas, meaning not simply a structural reversal, but the liberation of human cognitive and emotional capacities from the normative constraints of social roles (Turner, 1982).

Exploring how anti-structure and communitas are generated, a particular resemblance can be noticed between liminality and the collective effervescence which is produced through the ritual process of social interaction (Olaveson, 2001). As summarized by Randall Collins' (2004) model, based on the work of Durkheim and Goffman, every time two or more people meet physically, direct their attention on the same shared focus, and channel a common emotional mood towards the same objects, individual energies are catalysed and multiplied, and further contribute to the collective charge. The gradual rhythmic harmonisation of gestures transforms individual feelings into collective ones, and helps the participants to feel they are part of a moral 
community. The objects invested with the common attention and emotions become sacred for the participants as symbols of their unity. Nonetheless, the more the group polarizes around a unique and uncontested focus of emotional/cognitive entrainment, the more it tends to strengthen its external boundaries (Saint-Blancat, 2008). Furthermore, besides this insiders/outsiders classification, the ritual mechanism also generates an internal stratification 'between ritual leaders and ritual followers', as 'some individuals are more privileged than others, by being closer to the centre of the ritual than others' (Collins, 2004, p. 41).

The ritual process is therefore ambivalent: its de-structuring dimension generates a liminal condition by blurring boundaries and melting identities, while its restructuring dimension turns collective effervescence into group solidarity and crystallizes new boundaries. While Durkheim (1912) seems to be more interested in the latter dimension, Turner focuses on those liminal moments and situations in which people perceive themselves as 'part of a homogeneous, unstructured communitas, whose boundaries are ideally coterminous with those of the human species', and therefore 'differs from Durkheimian "solidarity", the force of which depends upon an in-group/out-group contrast' (Turner, 1982, p. 132). Moreover, Turner's idea of communitas and anti-structure refers to 'a relationship between person and person... which... does not submerge one in the other but safeguards their uniqueness in the very act of realizing their commonness' (Turner, 1974, p. 274).

However, Turner is aware that communitas ' is necessarily a transient condition if society is to continue to operate in an orderly fashion' ( ibid., p. 274). The fluidity of liminality tends to crystallize into new boundaries and classifications, both outside and inside the ritual. Therefore our initial question could be reformulated as follows: how can internal and external fluidity be prolonged as long as possible? The hypothesis gradually emerging through our research is that liminality and communitas may be 
better achieved when the collective event is shaped as a multifocal/polycentric ritual. This would explain why many inclusive sport festivals often place sport games within a wider range of other leisure and cultural activities: by multiplying the sources of collective effervescence, the organizers provide each participant with several opportunities to become a protagonist of the event, thus attracting and simultaneously celebrating different groups and individuals. Not being based on a unique recognition criterion, such a multifocal/polycentric ritual has the potential to turn diversity into a common ground for interaction. At the same time, by spreading the intensity of collective energies through a wider and differentiated range of ritual foci, the external boundaries might remain more blurred/porous and favour the inclusion of outsiders.

Additionally, the blurring of social boundaries is often obtained by 'desportizing' the sport activities. Examples of this include partly downplaying their competitive dimension, making sporting categorizations more fluid (through mixedgender and mixed-generation activities), and breaking down the separation between protagonists and spectators. By contributing to the carnivalesque character of the event (Bakhtin, 1965), these elements enhance its subversive potential. While in modern performance sports diversity is classified into rankings and hierarchies, here it contributes to the festive atmosphere in which corporeal practices are enacted: the more heterogeneous and strange the participants, the more colourful and entertaining the event. As a plurality of events is taking place simultaneously, no single focus of attention wins the day and each participant can be considered to belong to a minority (Eichberg, 2010).

In considering the MA as an exemplary case of these multifocal sports-rituals, we intend to observe (1) how their anti-structural liminality blurs internal and external boundaries, and (2) how the ephemeral character of such liminiality makes it difficult to maintain it over time. 


\section{Research setting and methodology}

The origins of MA lie in 1997 when the Progetto Ultrà Association initially invited some rival ultras groups to play a seven-a-side non-competitive football tournament, camp together, and discuss issues around violence and discrimination. Subsequently, the organizers gradually involved groups of migrants, social and political activists, and other people mainly attracted by the tournament's playful atmosphere, thus turning the event into a broader anti-discriminatory intercultural festival and opening it up to a wider audience. Since 2004 between 6,000 and 8,000 participants have attended the MA every year, from many different countries. In 2004, most teams were mixed-gender. In 2007, almost half of the teams were composed of people of different nationalities. New social and cultural activities have been added each year, such as round tables, book presentations, workshops, concerts, and video-projections. A basketball tournament was added to the sport programme in 2004 , followed by volleyball in 2006 , rugby in 2007 , and cricket in 2010 .

After initially being held in the small village of Montefiorino (1997-1999), the increasingly crowded festival moved to three different locations, all of them in Emilia Romagna, Italy: Montecchio Emilia (1999-2006), Casalecchio (2007-2010), Bosco Albergati (since 2011). The event is staged in a big park, where the organizers set up several sport pitches (18 for seven-a-side football, two for volleyball, two for rugby, and one each for cricket, basketball, and softball), two wide marquees for the restaurants, one for the concert-arena, one debating area called Piazza Antirazzista (Antiracist Square), plus five other stands for bars, smaller concerts and DJ-sets, video-projections, and information points. A wide camping area with showers and toilets is also provided, where the varied groups of participants sleep side by side and share four/five days of holiday atmosphere. Restaurants and bars are managed by dozens of volunteers - most of them are participants who gradually got involved in running the event - and their 
revenues supplement the institutional funding raised by Uisp to enable participants' free attendance. The MA takes place every second week of July, running from Wednesday to Sunday. Restaurants and bars open on Wednesday, when the social and cultural programmes begin. The football tournament and concerts start on Thursday. The peak of attendance is on Friday and Saturday, when the basketball, volleyball, rugby, cricket, and softball tournaments are played.

This paper is based on ethnographic research conducted over six years of attending the MA, from 2006 to 2012, in compliance with the ethical principles set out in the guidelines of the University of Padua and the Italian Sociological Association. The event was followed in almost its entirety (four days) in 2006, for three days in both 2007 and 2008, one day in 2009, four in 2011, and one in 2012. Observation was carried out daily up to a maximum of 14 hours, from 10:00 in the morning to two the following morning (02:00). In the crowded public space of the MA, some practical and ethical issues had to be necessarily managed through 'realistic and pragmatic solutions' (Fleming, 2004, p. 147). The researchers' identity was revealed to the interviewees, though clearly this was not feasible for the MA as a whole. Ease of access to the park and the playing fields constituted a first and relevant demonstration of the essentially inclusive and non-discriminatory character of the event. The heterogeneity of the participants and their physical appearance minimised the risk of the researchers seeming to be an extraneous presence and arousing suspicion.

The development of collective enthusiasm was monitored during the entire event by observing the evolving intensity of activity-participation during the initial, middle and closing stages of each MA. The different foci of attention were mapped by observing the number and type of participants in the various activities. The location of the different activities within the festival area and their distribution over the programme were also noted, considering the spatial and temporal density/proximity of the foci of 
attention as an indicator of the event's multifocality. Likewise, we considered the weight/centrality of each focus of attention within the event (notably sport compared to other foci). Furthermore we observed the form of sport activities and their positioning within the continuum sport-game-play, i.e. whether they were organised and perceived as highly-structured and standardized competitive performances (Guttman, 1978) or rather as fluid and inclusive playful games (Eighberg, 2009). Our longitudinal presence in the field made it possible to notice the impact of some relevant contextual changes, in particular the event being moved to different locations, and the crisis of the increasingly stigmatised and repressed ultras movement, with the consequent decrease in ultras participation in the MA.

Ethnographic observation was complemented by semi-structured in-depth interviews $^{\mathrm{i}}$ conducted during the tournament in 2006, 2007 and 2011 with key informants (the main tournament organiser, the president of UISP, two local administrators of the hosting municipality) and thirteen subjects belonging to the different types of participant team (ultras groups, social workers, members from various associations, simple event sympathisers) based on what Patton (1990, p. 179) describes as opportunistic sampling, partly supplemented by snowball sampling. The aim was to focus on a limited range of information-rich cases to progressively test and redefine the theoretical and analytical framework gradually emerging from the observational data. The interviews sought to investigate which of the event's foci the participants perceived a higher involvement in, and where they felt they were protagonists and had more opportunities to meet, communicate with and get to know new people belonging to different groups. The interviews also aimed to collect participants' narratives and representations related to changes that occurred in the MA's ritual configuration over time. Therefore, when possible, we preferred to interview experienced participants who were able to offer a longitudinal account of the event. The duration of interviews ranged 
from 35 to 95 minutes and they took place at the festival site to better capture the energetic effervescence and emotional involvement generated by the event (though, in relatively quiet and secluded locations to guarantee the necessary calm and facilitate recordings).

Conversational field notes were constantly taken, while video-recordings were collected in 2006 and 2007. The stages preceding and following the event were monitored via the MA website. The interpretations and representations promoted by the organisers were compared with the results of our field observations and with data gathered from participants. Field notes and interview transcripts were interpreted after being coded and separated into thematic areas with regard to the event's multifocality, the role played by sport within the event (and the way it is combined with other activities), and the form/shape of sport activities (how they are organized, managed and regulated).

\section{Blurring internal boundaries: multifocality and de-sportization}

The difficulty of precisely defining the MA testifies to its liminal and indefinite character, which keeps it open to different participants. A member of a football fans group, involved both as a player and a volunteer in the bars, attempted to describe the event as follows:

It is definitely a meeting of people who deal with such stuff as solidarity, antiracism, things like that... What are the objectives? Difficult to say, I mean... in our case, apart from playing football, which we like, and coming here to work, and meet friends... By the way, a lot of different sports are played here, now there's rugby, volleyball, I mean, people come and have fun, do sport, talk about things, there are debates, workshops, exhibitions, cinemas, documentaries... I mean, we also talk and discuss things here, it's not just playing football and sweating. I would say it's a big meeting. What unites everybody? Definitely the spirit of togetherness, of such things... And sport, which has always been a tool 
for unity, isn't it? sport unites - I mean popular sport, not the elite sport run by the bosses like Murdoch and his ilk, which we follow like idiots - but look at how many people play together in the same team leaving political and social issues apart...

Although the football tournament provides an important motivation, this participant also celebrates as 'sacred objects' the commitment towards solidarity and antiracism, as well as the spirit of togetherness and camaraderie. Moreover, he highlights how a plurality of sport and cultural activities provides different foci of attention which catalyse and feed collective energy. Each of these contexts of interaction can provide occasions for intergroup contact and social mixing, as pointed out by this member of the Bologna ultras group who is also involved as a volunteer:

It is in the evening, when partying under the marquees, that it's easier to get to know new people. Or it can happen that you get to know someone during the matches. Probably because there's the direct contact, as in the marquee. Under the marquee, within the general euphoria, you start to exchange opinions. It's happened to me quite often. Also, we have been volunteering here in the bars and restaurants with the supporters from Modena for many years, and then recently with those from Parma as well, and we got to know them by working together here, even though we are rival fans, ... when you work together, it can be a meeting point.

High energy levels can be experienced after the evening concerts, when the fans meet in the large restaurant-tents and create spectacular, spontaneous choreographed performances, singing anthems in unison, jumping on tables and drumming the beat with hands and feet. These improvised performances continue through the night, and the majority of the gathered people are gradually enraptured by this hypnotic fusion (Eichberg, 2009). Although such performances have become less frequent and not as massive after the slight decrease in the number of ultras participating on the event, they still represent one of the most intriguing generators of collective effervescence within 
the festival.

However, among the event's ritual foci the football tournament still has the greatest relevance, notably for the interpersonal/intergroup exchange opportunities it provides. A member of a mixed team of Italian volunteers and (mainly African) refugees and asylums seekers, explains it as follows:

In my opinion, there are two distinct MA: the one that you play, and the one that you experience in the rest of the event... Therefore, if you actively participate in the tournaments - whichever of them, from football to other sports - you really get to understand what the MA truly is. Because... because it is in the game, that one is the field in which you materially recognize the other: you touch him, you stick to him with the sweat, you hug him at the end, you smile, you learn... I mean, there's really an evolution: the first time, you come and you want to win. The second time, you want to win but... you already know someone, you greet him. The third time, the most important matches are the friendly ones, and you don't give a damn about the tournament anymore! And I'm stating this, even though our team almost always qualifies for the final rounds...

Interpreting these words in ritual terms, the sacred object on which participants focus their attention and emotions is no longer game scores and results, but rather the sociable and festive atmosphere of enjoyment (Simmel, 1908; Giulianotti, 2005). In this perspective, many forms of diversity - even the more bizarre (for instance, during our ethnography we saw a mixed-gender team playing their matches wearing red female lingerie) - acquire value as enriching elements (Eichberg, 2009). The grotesque bodies thus contribute to the carnivalesque and playful atmosphere of the event (Bakhtin, 1965).

Nonetheless, a series of measures has to be adopted to downplay the competitive dimension and foster the participative one. In fact, in the first years not all participating teams seemed to acknowledge and respect the spirit of the event. Especially in the second part of the tournament, when matches became more competitive and players 
were increasingly tired, the intrinsically oppositive character of football matches (Armstrong \& Giulianotti, 2001) tended to elicit a certain amount of conflict, which has also been observed in other similar events (Burdsey, 2008). The MA organisers have so far managed these potential tensions by creatively adapting the tournament's rules and ritual form. First of all they decided to have the semi-finals and the finals directly as a penalty shootout rather than playing a match. Spectators are allowed to enter the playing field and happily surround the goal and the players taking the penalty kicks. This shifts the ritual form of the event from 'battle' to 'lottery': there is a different kind of tension, since destiny and luck become more influential than sport-specific skills.

I mean, winning a tournament when you've played all the shootouts at penalties, it's no more the same game that you've been playing in the early rounds. I mean, it's something different. Hence, you know that you came here just to play, and afterwards, just because the tournament has to finish somehow, we take the penalties... but, I mean, we could do it by playing pinball, or odds and evens, it would be the same! Therefore, you accept this from the very beginning...

An additional device used by the organizers to downplay the relevance of the football achievements is evident in the prize-giving sequence at the final ceremony. Indeed, the most important trophy - the one which is awarded at the end of the ceremony - is not the award for the winners of the tournament, but the Antiracist Cup, awarded to the team who best upheld the spirit and the ideals of the tournament during the entire year, challenging discrimination in its local context. Other important awards include the Fair Play Cup, the Friendship Cup, and the Kick Sexism Cup. The cup for winning the football tournament is awarded halfway through the ceremony: it is just one of the many awards. Friendliness, fairness, and engagement are thus celebrated as sacred objects of the rite, subverting the usually prominent celebration of sports performance (Loland, 2000). 
The continuous organisational adjustments undertaken to downplay the competitive/performance dimension of the football tournament help to moderate its relevance in comparison to the other ritual foci, thus balancing and fostering the MA's multifocality. Besides, they also render sport categorizations less necessary, thus keeping the event open to participants with very different technical and physical characteristics and abilities:

Elderly teams can play here, as well as male-female mixed teams, children's teams... Last year we played a children's team! I mean, when we arrived on the pitch and I saw them, I couldn't believe it... Once, in Montecchio, I played a man who was about 75 years old, but you should have seen him, he ran like a marathon runner... and you say: look how beautiful it is, here everybody plays, here we all play, I mean children, elderly... This is certainly a strong glue. I tell you, we've been coming here for eight years, and there are teams I keep seeing, for eight years they are always the same; we are growing old, but nobody misses a year. And we take holidays to come here!

The de-categorization of sport activities (notably football) through gender- and agemixed teams helps to blur internal boundaries, preventing internal separation within the event's community, and to avoid reproducing the usual representation of sport as a fitadult-male-dominated interaction context.

\section{Blurring external boundaries}

Besides preventing internal separations and classifications, the event's liminality is also fostered by keeping it open towards outsiders, to begin with the inhabitants of the hosting community. Like a small Woodstock of sorts, the area of Montecchio where the event was held up until 2006 was flooded by several thousand strange, noisy and colourful people. They were highly atypical in looks and behaviour compared to the local population, who initially tended to show a certain degree of suspicion. In the first years, the organisers had to act as mediators in order to limit annoyance caused by the 
behaviour of some participants:

We also had some colourful episodes, like ... the members of a team distinguished themselves by playing all their matches in the nude, and they went as far as even going naked to the supermarket! Clearly, many were annoyed by the whole thing. Then the guys understood the difficulties they were creating, and we found a good compromise: they got to play naked, but on a field that was a bit more out of sight.

Facing these initial difficulties, the organisers have developed activities to promote and favour contact and mutual acquaintance between the participants in the tournament and the hosting community:

(...) we began having a parade which brought all participants in the tournament to the town centre. It was a way to let people know us, by bringing the town a festive parade, with fireworks, music, etc. The town square filled with people, and from that moment on, even the local population started coming to the festival: it was a radical change.

Drummers and dancers led the parade, followed by all the event's participants, among which the most colourful and noisy were the ultras groups, as recalled by one of their members:

The parade was wonderful! I mean, the flags of all the teams, the banners of all the associations... In Montecchio we were in a park, then you walked a short street and reached the centre of the village. And, in the centre, the whole village welcomed us. One year, I remember, all the children with... you know, the little stars, those like fireworks... I mean, amazing! Also, it was nice because you could go to the village to take a coffee with the elderly people... At that time (...) the people of the Mondiali were very colourful - I mean, outside the bar you were really likely to see some elderly sitting beside a punk with a crest that high and the combat boots! - nonetheless, it seemed to me that they were exellent livingtogether. Then of course, maybe when those people go home they say: 'Ah, these guys, they're all covered in tattoos and piercings!' However (...) they surely saw the best side of the ultras, therefore they couldn't complain that much. I mean, they saw the beautiful moment, the festive one, with all those flags, the banners, the smoke candles, the fireworks... It was the best face that we displayed. 
As opposed to what otherwise usually happens (Spaaij, 2008, p. 387), during the MA ultras did not march through the town exhibiting their aggressive potential (Marsh, 1978) and attempting to intimidate bystanders with their threatening attitude (Katz, 1988, p. 142). Rather their parade at the MA was aimed at stressing the festive and colourful dimension of football enthusiasm, by staging collective performances similar to those of the Scottish Tartan Army (Giulianotti, 1995) or of Danish roligans (Peitersen, 2009), arousing curiosity and fascination rather than fear in the general public. Thereby, ultras experienced the opportunity to get positive external recognition without resorting to the exhibition of hard masculinity through violent confrontation.

Parading through the town helped to add fluidity to the event's ritual boundaries and minimize its self-referentiality. Nonetheless, when the MA's increasing participation became hardly sustainable for the small local community of Montecchio, the organizers were forced to move the event to a broader area outside Casalecchio, near Bologna, thus facing new challenges. On the one hand, the new location was quite far from the built-up area and the parade lost most of its energy along the way before reaching the local inhabitants, thus partially failing to impress them. On the other hand, being within easy reach of a big city like Bologna, the new location attracted a huge attendance which the organizers found difficult to control (the subsequent problems will be analysed in the following section). In fact, although the aim of the MA is to remain as open as possible to all the people who want to join, the organisers also need to keep a certain degree of control over the social dynamics engendered by the event, particularly with the participation in the football tournament. Diversity has been preserved by selecting applicants so as to guarantee participants' pluralism (thus mixing ultras, migrants, anti-racist associations, LGBT groups, human rights activists, social workers, disabled, and other formal or informal groups). A limit on the (otherwise excessive) 
number of teams from Italy, Germany and Austria was also occasionally established to maintain a broader geographic and cultural diversity among the participants.

Apart from this, participation/attendance is open to every group and individual. This porosity of the external boundaries, together with the different sporting, musical and cultural opportunities provided by the event, helps to attract different types of people and fosters social mixing, as confirmed by this member of an ultras group:

\footnotetext{
We, as a group, have really liked the fact of mixing together with other people, not only ultras groups. I've built up friendships here, people whom I see once a year, and as we see each other from far away, we hug each other, and go for a drink. People of the Mondiali, let's call them the 'non-ultras': participants, old teams which we might have played in the past, people whom we challenged maybe eight years ago... I give you an example: the Calici Rossi [Red Chalices], people with grey hair, a lot older than us, who played very tough, they played a really tough match and... with these people, although I can't remember any of their names, we meet every year and say: 'Fuck, you're always here! You're still playing!' And meeting teams like that, it is an enriching experience for us. I always say, when talking with my mates, that we have improved here. (...) we owe a lot to the Mondiali, 'cause we've got better. Maybe it's also because we've got older. Anyway... we arrived here eight years ago, and now we're better. Because... because we've mixed up with other people, who are totally different from us, and I believe that when things mix together, they get better. They don't get worse, they get better.
}

The MA's anti-structure has therefore proved to be quite effective in creating liminal spaces for social mixing. Nonetheless, as Turner (1974) himself warned, it is hard to prolong such liminality. Internal and external boundaries of the event tend to crystallize into new tensions and separations, leading to problems and limitations which need to be explored.

\section{Problems and limitations: the transience of liminality}

Despite the relative success of the MA in fostering social encounters between different 
participants, social mixing does not necessarily lead to the fostering of positive attitudes towards diversity. Quite predictably, among the liminal relations enabled by the event, the cohabitation between rival ultras groups was one of the first to crystallize back into the old separations. However, similar dynamics emerged also in the relationship between ultras and non-ultras participants. On the one hand, the latter tend to lay the blame on the self-referential attitude of the former, as exemplified by this non-ultras participant:

The Mondiali have also been an attempt to open the ultras' world towards other experiences, thus getting out from its self-referentiality. But then, the ultras group is the ultras group. During the parades in Montecchio, for instance, it happened that some of them threw fireworks into gardens... of course, there were maybe only four of five of them, but there you can see their mentality... they lacked sensitivity to understand that, in a context where you are trying to convey a message, an act like that is enough to ruin everything and raise a wall between you and the local people, while you are trying to communicate... I mean, their identity-element is the group, what matters to them is to preserve the group. While to me, a supporter of a football team, what matters is to protect the name and colours of my team.

On the other hand, ultras sometimes felt as if they were stigmatised by the other participants and also unfairly deprived of 'their' festival:

It's really important to highlight that this event was born thanks to the ultras, therefore it isn't fair that now other associations, whose names I don't want to mention, perceive it as their own event, just because in the last few years they've shown up...

In some aspects it has changed perhaps, as now you can meet associations who are maybe too... bourgeois, or at least intellectualoid, who perhaps don't understand some things...

(...) more than one person has been heard saying: "Hey, that one is the ultras bar!", as if they were keeping their distance. While actually there are ultras who take one week's holiday to manage bars and restaurants, thus supporting the event.

Another controversial dimension, which highlights discrimination, stereotypes and 
separations within the event, is constituted by gender relations. For instance, a group of university students, usually committed to promoting antiracism and anti-sexism in their local milieu, experienced some unpredicted challenge when its male members resisted the idea of forming a mixed team together with their female mates. Wishing to form a competitive team, they misrecognized both the non-competitive spirit of the tournament and the desire of the girls to be part of the team, thus reproducing the male hegemonic criteria that generally dominate mainstream sports. Nonetheless, this kind of controversy - and the subsequent cognitive dissonance - also represents an opportunity to generate reflexivity among the participants, bringing to light the contradictions between their statements of principles and their everyday practices. This is well exemplified by the story of a group of football fans who questioned the fairness of their own official name 'Sampdoria Rude Boys' after reading an anti-sexist leaflet distributed by a German team, and eventually decided to change it to the more inclusive 'Sampdoria Rude Boys \& Girls'.

Floating between the wish to preserve the original spirit of the event and the aim to enlarge the antiracist (and anti-discriminatory at large) community, organizers and participants alternate exclusive and inclusive attitudes. For instance, the recent move from Casalecchio to the harder-to-reach location of Bosco Albergati in 2011, despite being mainly for logistic and institutional reasons, was also partly influenced by the concern that the event might be ruined by an excessive attendance of (unaccountable) external visitors. Although understandable, the need to protect the MA from uncommitted visitors and potential troublemakers may nonetheless contribute to enhance the event's self-referentiality, limiting its potential to attract those people who do not already share an antiracist ethos, as remarked by this participant:

Someone who is right-wing oriented, or moderate, or anyway who's not left-wing oriented, and comes here... well, there might be some individuals. But a whole 
group... I don't think so, neither a moderate one. I mean, a right-moderate group which openly declares themself to be antiracist... I don't think it exists.

However, the event's effectiveness should not be seen principally in its capacity to 'convert' racists to anti-discriminatory stances, but rather in its contribution to reinforce the antiracist movement, especially in contexts characterized by recent globalized migration and increasing discrimination at both social and political levels. As one participant observed:

Well, first of all, if the Mondiali never existed, would you ever imagine that 10,000 people could arrive and 204 football teams could play all together on a pitch for four days? No. I mean, it seemed something crazy. Nonetheless, it happened. Therefore it can actually be done. This event demonstrates that this country still has something good to say. (...) it's inclusive, it involves people, and shows that we are not only those of repatriations, of the CIE [Italian Centres for Identification and Expulsion of illegal migrants], and Maroni's speeches [Italian Minister of the Interior]. We need to say it, in Italy, that there's someone who is against these racist policies.

Besides creating a 'subjunctive world', in which the status quo can be challenged and new possibilities can be explored, the MA enables antiracist activists and sympathizers to meet, see, and touch each other, thus realizing that they exist as a tangible collectivity. Like in many other sport-for-development initiatives, the event pulse provides an important boost to keep participants 'alive' by supplying 'much needed excitement, animation, enthusiasm and vibrancy' (Schulenkorf \& Adair 2012, p. 3). Hence, such a Durkheimian self-celebration regenerates their feeling of being part of a moral community. Furthermore, the collective effervescence generated by the MA is renewed and spread through new local events, often organized according to the MA's format, as exemplified by this ultras' statement:

In Genova, we put on our own tournament every year. We bring there ultras groups from other cities, friends of ours, together with other Sampdoria supporters from 
Genova, and migrants as well. Latinos, gangs, and the likes, went to play with us and the ultras. Thus, the richness that we've learnt here at the Mondiali, we brought it home too. I mean, that tournament that we put on, it would never have been born if we hadn't come here eight years ago, because everything starts from here. Hence, I repeat, it's a seed that was sown; afterwards, everyone made his own garden at his home. It surely taught many people here, the same way it taught us.

One of the main legacies of the MA can be considered to be how its ethos has spread, inspiring lots of similar events in other local contexts where the different participants live.

\section{Conclusions}

According to our analysis, the organizational design of the MA contributes to shape a liminal space which provisionally de-structures the usual social categorisations and representations. Nonetheless, the multifocal nature of the event produces ambivalent effects. While the porous boundaries of the festival allow for diversification among participants and prevent the creation of a self-referential, closed and monolithic community, this also causes constant exposure to the opposite danger of excessive fluidity. The great success of the festival and its quantitative growth recently drove the organisers to oscillate between measures aimed at gaining wider participation, and measures aimed at preserving the original ethos of the event.

The MA proved to be capable of creating a fluid, open and heterogeneous communitas. However, it clearly exhibits a tendency towards differentiation and crystallisation, both inside and outside this communitas, as well as difficulty in maintaining its liminal condition. Such ritual configuration seems destined to ineluctably exclude some forms of diversity, creating a sense of "us" that cannot do without a "them" (Baumann, 1992). Thus, the idea of 'diversity as a shared value' seems to be an oxymoron, a paradox which cannot be actualised. Despite these 
fragilities (or maybe just because of them), the MA remains a remarkable testing ground for social experimentation, confirming the socio-political potential of those leisure events in which new forms of embodied multicultural interaction can be prefigured (Woodward, 2009).

Although a certain degree of self-referentiality can be noticed in the tendency to mainly attract people who supposedly already share similar orientations, the festival promotes the anti-discriminatory culture by providing participants with many opportunities to test their real behaviour towards diversity. Hence, the MA becomes a metaphorical gym where participants can enhance their reflexivity by practising and training their anti-discriminatory culture, bringing under discussion their attitudes and sometimes revising their own idealized self-representation. Furthermore, the festival has provided the participants with a model to generate several spin-off activities in their local contexts. Since multifocality and de-sportization tend to be common features in many of these events, we argue that further exploration of these dimensions would usefully contribute to the development of comparative interpretive frameworks for the study of sport-for-inclusion dynamics.

\section{References}

Armstrong, G., \& Giulianotti, R. (Eds.) (2001). Fear and loathing in world football. Oxford: Berg.

Bakhtin, M. M. (1965) Rabelais and His World. Translated by Hélène Iswolsky. Cambridge, MIT Press, 1968. Reprint, Bloomington: Indiana University Press (Midland Book), 1984.

Baumann, G. (1992). Ritual implicates "Others": Rereading Durkheim in a plural society. In D. de Coppet (Ed.), Understanding Rituals (pp. 97-116). London: Routledge.

Burdsey, D. (2008). Contested conceptions of identity, community and multiculturalism in the staging of "alternative" sports events: a case study of the Amsterdam World Cup football tournament. Leisure Studies, 27(3), 259-77. 
Chalip, L. (2006). "Towards social leverage of sport events", Journal of Sport \& Tourism, 11, 109-127.

Coalter, F (2007). A Wider Social Role for Sport: Who's Keeping Score? London: Routledge.

Collins, R. (2004). Interaction Ritual Chains. Princeton: Princeton University Press.

Dallaire, C., \& Denis, C. (2005). Asymmetrical hybridities: youths at Francophone Games in Canada. The Canadian Journal of Sociology, 30(2), 143-168.

Durkheim, É. (1912). Les formes élémentaires de la vie religieuse. Le système totémique en Australie [The elementary forms of the religious life: The totemic system in Australia]. Paris: Alcan.

Eichberg, H. (2009). Sport as festivity: Towards a phenomenology of the event. Sport, Ethics and Philosophy, 3(2), 215-236.

Eichberg, H. (2010). The people of democracy. Towards a philosophy of Sport for All. London: Routledge.

Elling, A., De Knop, P., \& Knoppers, A., (2003). Gay/Lesbian Sport Clubs and Events: Places of Homo-Social Bonding and Cultural Resistance? International Review for the Sociology of Sport, 38(4), 441-456.

Falassi, A. (ed.) (1987). Time out of time: Essays on the festival. Albuquerque: University of New Mexico Press.

Fleming, S. (2004). Qualitative Research into Young People, Sport and Schooling: The Ethics of Role-Conflict. In A. Tomlinson \& S. Fleming (eds) Ethics, sport and leisure: Crises and critiques ( $2^{\text {nd }}$ ed) (pp. 137-50). Oxford: Meyer \& Meyer Sport.

Gasser, P.K., \& Levinsen, A. (2004), Breaking post-war ice: Open Fun Football Schools in Bosnia and Herzegovina, Sport in Society, 7 (3), 457-472.

Giulianotti, R. (1995). Football and the politics of carnival: An ethnographic study of Scottish fans in Sweden. International Review for the Sociology of Sport, 30(2), $191-220$.

Giulianotti, R. (2005). The sociability of sport. International Review for the Sociology of Sport, 40(3), 289-306.

Guttman, A. (1978). From ritual to record: The nature of modern sport. New York: Columbia University Press.

Handelman, D. (1990). Models and mirrors: Toward an anthropology of public events. New York, NY: Berghahn Books. 
Hemingway, J. L. (1999). Critique and emancipation: Toward a critical theory of leisure. In E.L. Jackson \& T.L. Burton (Eds.), Leisure studies: Prospects for the twenty-first century (pp. 487-506). State College, PA: Venture.

Katz, J. (1988). Seductions of crime. New York: Basic Books.

Krowel, A., Boonstra, N., Duyvendak, J.W., \& Veldboer, L. (2006). A good sport?: Research into the capacity of recreational sport to integrate Dutch minorities. International Review for the Sociology of Sport, 41(2), 165-180.

Loland, S. (2000). The logic of progress and the art of moderation in competitive sports. In T. Tännsjö \& C. Tamburrini (Eds), Values in sport: Elitism, nationalism, gender equality and the scientific manufacture of winners (pp. 39-56). London: Routledge.

Long, J., \& Sanderson, I. (2001). The social benefits of sport: Where's the proof? In C. Gratton \& I. Henry (Eds.), Sport in the City (pp. 187-203). London: Routledge.

Mair, H. (2002/03). Civil leisure? Exploring the relationship between leisure, activism and social change. Leisure/Loisir, 27(3/4), 213-237.

Marsh, P. (1978). Aggro: The illusion of violence. London: Dent.

Olaveson, T. (2001). Collective Effervescence and Communitas: Processual Models of Ritual and Society in Emile Durkheim and Victor Turner. Dialectical Anthropology, 26, 89-124.

Patton, M. (1990). Qualitative evaluation and research methods. Beverly Hills: Sage.

Peitersen, B. (2009). Supporter culture in Denmark: the legacy of the 'World's Best Supporters'. Soccer \& Society, 10(3/4), 374-385.

Ruzza, C. (2008). The Italian Antiracist Movement between Advocacy, Service Delivery, and Political Protest. International Journal of Sociology, 38 (2), 5564.

Saint-Blancat, C. (2008), L'islam diasporique entre frontières externes et internes [Diasporic Islam between internal and external boundaries]. In A. CapellePogacean, P. Michel, \& E. Pace (Eds.), Itinéraires européens: nation(s) et religion(s) à l'épreuve du pluriel [European itineraries: nation(s) and religion(s) facing the challenge of pluralism] (pp. 41-57). Paris: Presses de Sciences Po.

Schulenkorf, N. (2010). Sport events and ethnic reconciliation: attempting to create social change between Sinhalese, Tamil and Muslim sportspeople in war-torn Sri Lanka. International Review for the Sociology of Sport, 45(3), 273-294. 
Schulenkorf, N., \& Adair, (2012). Temporality, transience and regularity in sport-fordevelopment: synchronizing programs with events. Journal of Policy Research in Tourism, Leisure and Events, 5, 99-104.

Sharpe, E.K. (2008). Festivals and social change: Intersections of pleasure and politics at a community music festival. Leisure Sciences, 30(3), 217-234.

Sherry, E. (2010). (Re)engaging marginalized groups through sport: The Homeless World Cup. International Review for the Sociology of Sport, 45(1), 59-71.

Simmel, G. (1908). Soziologie. Leipzig: Duncker \& Humblot.

Sorek, T. (2003). Arab soccer in Israel as an "integrative enclave". Ethnic and Racial Studies, 26, 422-450.

Spaaij, R. (2008). Men like us, boys like them: Violence, masculinity, and collective identity in football hooliganism. Journal of Sport and Social Issues, 32, 369392.

Sterchele, D. (2007). The limits of inter-religious dialogue and the form of football rituals. Social Compass, 54(2), 211-224.

Sugden, J. (2006). Teaching and playing sport for conflict resolution and co-existence in Israel. International Review for the Sociology of Sport, 41(2), 221-240.

Turner, V. (1967). The forest of symbols: Aspects of Ndembu ritual. Ithaca: Cornell University Press.

Turner V. (1974). Dramas, Fields, and Metaphors: Symbolic Action in Human Society. Ithaca: Cornell University Press.

Turner, V. (1979). "Frame, Flow and Reflection: Ritual and Drama as Public Liminality.” Japanese Journal of Religious Studies. 6(4), 465-499.

Turner, V. (1982). From ritual to theatre: The human seriousness of play. New York: PAJ Publications.

Woodward, K. (2009) Bodies on the margins: regulating bodies, regulatory bodies. Leisure Studies. 28(2), 143-156.

\footnotetext{
${ }^{\mathrm{i}}$ Interviews were conducted in Italian (15) and Bosnian (2) and translated by the first author, who is bilingual.
} 